\title{
Assessment of Public Perception and Awareness of the Effect of Poor Solid Waste Disposal on the Environment in Jalingo Metropolis
}

\author{
Oruonye, E.D. ${ }^{1}$ \\ Tukura Ejati Danladi ${ }^{2}$ \\ Ahmed, Y.M. ${ }^{3}$ \\ ${ }^{1,2, s}$ Department of Geography, Taraba State University, P.M.B. 1167, Jalingo, Taraba State, Nigeria \\ 'Email:eoruonve@gmail.com
}

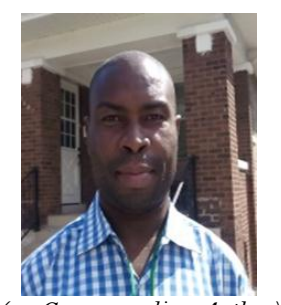

( Corresponding Author

\begin{abstract}
The study assesses the level of public perception and awareness of the effects of poor solid waste disposal on the environment. Data was collected through direct observation and use of questionnaire. The questionnaires were used to obtain the residents perception and awareness of waste generation and disposal methods in the study area. Five political wards (Barade, Majidadi, Sintali A, Turaki A and Turaki B) were purposively selected. The data were analyzed using descriptive statistics. From the study, 39\% of the respondents attributed the causes of poor waste disposal to indifferent attitude of the residents, $35 \%$ to lack of waste disposal facilities, $22 \%$ lack of waste services and $6 \%$ to institutional failure. The findings show that most of the wastes generated in the town come from residential households, market places, business shops, government and private offices and municipal areas. Most of the wastes are either disposed off the street or any nearby dumpsite (mostly unapproved and illegal). Most of the respondents claimed to be aware of what constitutes solid waste and effects of poor disposal. However, this claim negates attitude of indiscriminate solid waste disposal in the study area as revealed by the increasing number of open waste dumpsites and wastes that litters most streets of the town. There is need to properly managed the solid waste generated by daily activities of the people. This will help minimize the risk to human health and the environment. Based on the findings the study recommends increase enlightenment campaign through jingles in mass media, recruitment and empowerment of community health workers and sanitary officers and reactivation of the monthly environmental sanitation programme.
\end{abstract}

Keywords: Assessment, Awareness, Jalingo, Perception and Solid wastes.

Citation | Oruonye, E.D.; Tukura Ejati Danladi; Ahmed, Y.M. (2018). Assessment of Public Perception and Awareness of the Effect of Poor Solid Waste Disposal on the Environment in Jalingo Metropolis. Asian Review of Environmental and Earth Sciences, $5(1): 27-33$.

History:

Received: 27 June 2018

Revised: 2 August 2018

Accepted: 6 September 2018

Published: 29 October 2018

Licensed: This work is licensed under a Creative Commons

Attribution 3.0 License (cc)) Er

Publisher:Asian Online Journal Publishing Group
Contribution/Acknowledgement: All authors contributed to the conception and design of the study.

Funding: This study received no specific financial support.

Competing Interests: The authors declare that they have no conflict of interests.

Transparency: The authors confirm that the manuscript is an honest, accurate, and transparent account of the study was reported; that no vital features of the study have been omitted; and that any discrepancies from the features of the study have been omitte
study as planned have been explained.

Ethical: This study follows all ethical practices during writing.

\section{Contents}

1. Introduction .

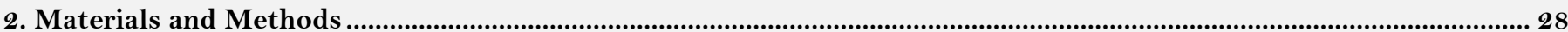

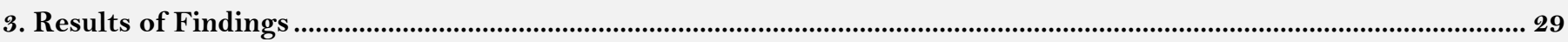

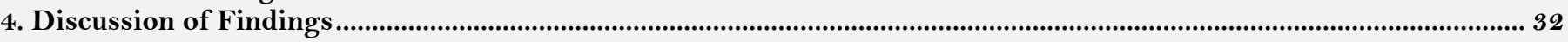

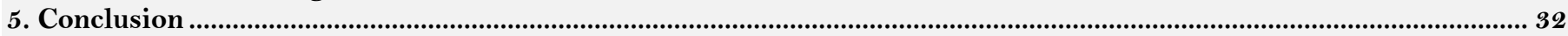

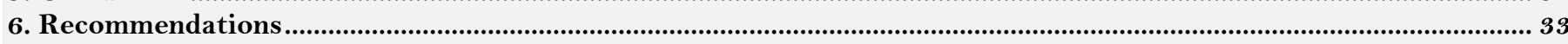

References ...1. 


\section{Introduction}

The increasing growth of urban centres in most developing countries of the world in recent time has resulted in increased consumption of resources to meet the growing demands of urban populations and industry. This situation result in generation of large amounts of solid waste in cities [1].

All human activities generate one form of waste materials or the other which may not be of immediate use and hence constitutes waste that is ultimately released into the environment [2]. Thus, waste is an inevitable byproduct of our daily activities. In the past, when human population was relatively small, solid waste issues were not a serious problem.

However, with urbanization and growth of large conurbations, the challenges posed by solid waste are becoming enormous. Solid wastes is made up of all the organic and inorganic waste materials that are usually non free flowing that is produced as a result of human and animal activities which have lost their value to the user and consequently discarded as useless or unwanted [3].

Solid waste is one of the most visible, immediate and serious environmental problems facing most municipal authorities in developing countries [4]. Consequently, this growing solid waste disposal challenges in developing countries is gradually approaching crises level. This trend of indiscriminate waste disposal has gone unchecked for so many years that the situation appears to be intractable.

In Nigeria, solid waste disposal problem is typified by overflowing dustbins, mountains of open refuse dumps at virtually every street and corners of the town; with their attendant problems (especially where burning occurs) and the existence of improperly operated landfills which are often rodent infested, with potentials for surface and ground water pollution [2].

The volume of solid waste generated in any urban centre is often a reflection of the intensity of human activities such as population, urbanization, social development, resource exploitation and unchecked technological advances. All these activities generate one form of waste or the other. The implication of this is that we have more solid waste to cope with than ever before [5].

Poor disposal of solid waste has adverse effect on the environment in general [6]. The issue of solid waste generation and its likely effects on the health, quality of environment and urban landscape have become burning national issues in Nigeria today.

All stakeholders concerned with the safety of our environment have come to realize the negative consequences of mounting solid wastes found in residential neighborhoods, markets, schools, and central business districts in our urban centres. These solid wastes have become recurring features in our urban environment. There is no gainsaying that our urban centres today are full of problems associated uncleared solid wastes [7].

There is increasing trend of indiscriminate dumping of solid waste in Jalingo town as in other major cities in Nigeria. This increasing trend is further made worst by the prevailing incidence of poverty, population explosion, decreasing standard of living, poor governance and low level of environmental awareness [8].

The perception of one's capability can be said to set a limit to what one can do and ultimately what could be achieved $[9]$. Owing to challenges of improper management and lack of public awareness, some major part of Jalingo town is heavily inundated with indiscriminate solid waste that constitutes health challenges to residents of the area.

The environmental degradation and health impact of poor disposal of solid waste can be seen in the contamination of both surface and ground water through direct waste contacts, air pollution by burning of wastes, spreading of diseases by different vectors like birds, insects and rodents, or uncontrolled release of methane by anaerobic decomposition of waste [10]. The health implications of improper solid waste disposal are enormous and cannot be ignored.

Solid wastes that are not properly managed can cause water pollution which may breed diseases like cholera, typhoid and others. Indiscriminate disposal of solid waste is a threat to human health. Inadequate disposal of solid waste is a major factor in the spread of gastrointestinal and parasitic diseases primarily caused by vectors.

At the moment, there is need to increase the level of awareness of the effects of poor solid waste disposal among residents in the town especially as it relates to open dumping of solid wastes and water pollution. This study examines the level of awareness and perception of the effect of poor waste disposal among residents of the study area.

\section{Materials and Methods}

Data for the study were collected through direct observation and use of structured and semi-structured questionnaire and interview methods. The questionnaires were used to obtain the residents views and ideas about waste generation and disposal methods in the study area. The questionnaire contains 25 questions that focused on knowledge of what constitutes waste, effective methods of waste disposal, poor waste disposal methods, health impacts of poor waste disposals, environmental pollution from improper waste disposal and problems associated with open dump sites among others.

Some waste dumpsites were visited in the selected wards. This affords the researcher the opportunity to see how wastes are disposed in the study area. Data were collected during the period from November to December 2017. One hundred and two (102) people were selected through simple random sampling technique. Five political wards (Barade, Majidadi, Sintali A, Turaki A and Turaki B) were purposively selected from the ten political wards in the study area because of the high population density, presence of poorly planned residential houses and proliferation of open waste dumps in the area. The data were analyzed using descriptive statistics. 


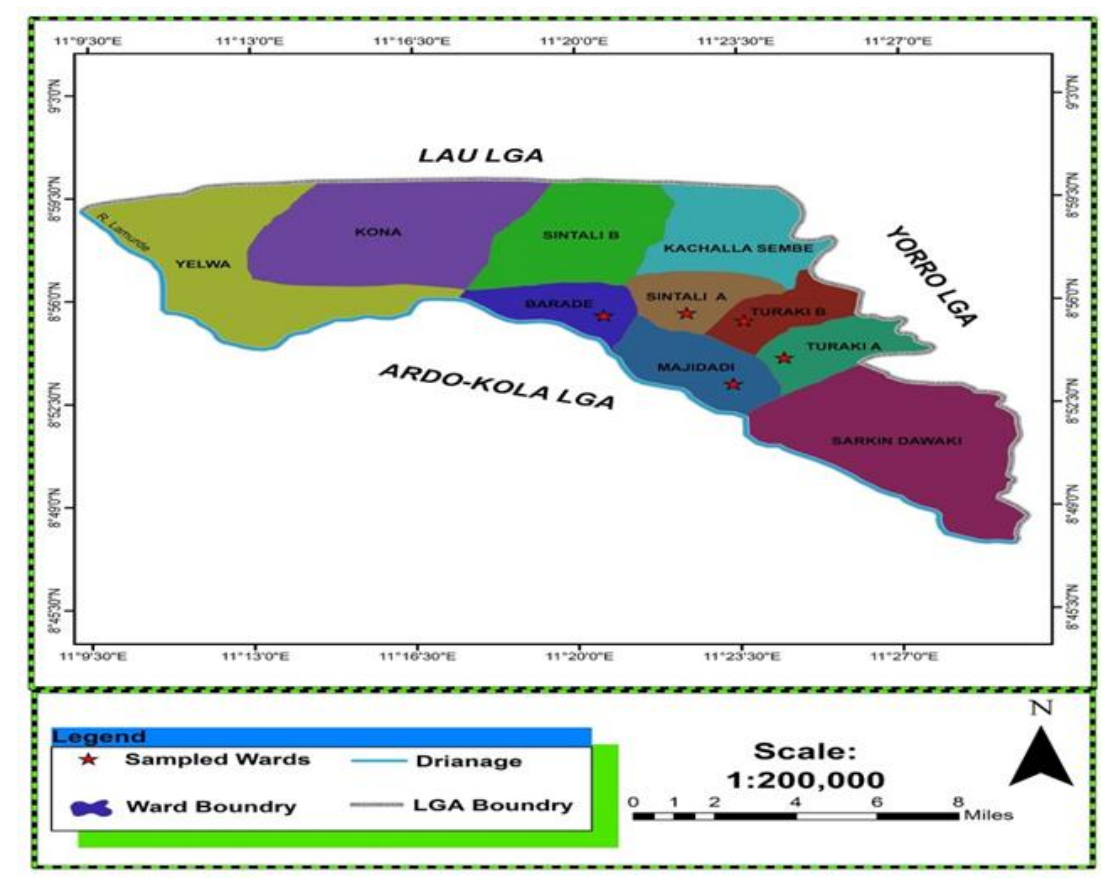

Source: Data analysis

Figure -1. Map of Jalingo LGA showing Sampled wards

\section{Results of Findings}

\subsection{Demographic Characteristics of Respondents}

Results of Findings Demographic Characteristics of Respondents The demographic data shows that 52\% of the respondents are male and $48 \%$ are female as shown in Table 1 below. The demographic data also shows that $43.1 \%$ are below the ages of 24 years, $22.6 \%$ are between $25-29$ years, $15.7 \%$ between30-34years, 3.9\% between $35-39$ years and $5.9 \%$ are between the ages of $40-44$ years and $8.8 \%$ are above $45 y$ years.

Age composition is important in order to ensure that participants were old enough to understand wastes and environmental issues [11]. The result also shows that $58.8 \%$ of the respondents are married, $35.3 \%$ are single, $3.3 \%$ are widowers, $1 \%$ widow and $1 \%$ are separated. In terms of occupation, $35.3 \%$ were unemployed, $31.4 \%$ are civil servants $14.7 \%$ are farmers, $4.9 \%$ artisans and $2.9 \%$ retired. According to Bogoro, et al. [6] the type of occupation does not only influence the type and amount of solid wastes generation, it also affects the waste disposal practices.

Table-1. Demographic characteristics of respondents

\begin{tabular}{|c|c|c|}
\hline \multicolumn{3}{|l|}{$\overline{\text { GENDER }}$} \\
\hline Gender & Frequency & Percentage (\%) \\
\hline Male & 53 & 52 \\
\hline Female & 49 & 48 \\
\hline Total & 102 & 100 \\
\hline \multicolumn{3}{|l|}{$\mathrm{AGE}$} \\
\hline Less than 24 years & 44 & 43.1 \\
\hline $25-29 y r s$ & 23 & 22.6 \\
\hline $30-34 y r s$ & 16 & 15.7 \\
\hline $35-39 y r s$ & 04 & 3.9 \\
\hline $40-44 y r s$ & 06 & 5.9 \\
\hline $45 y r s$ and above & 09 & 8.8 \\
\hline Total & 102 & 100 \\
\hline \multicolumn{3}{|l|}{ MARITAL STATUS } \\
\hline Married & 60 & 58.8 \\
\hline Single & 36 & 35.3 \\
\hline Widow & O4 & 3.9 \\
\hline Widower & 01 & 1.0 \\
\hline Separated & 01 & 1.0 \\
\hline Total & 102 & 100 \\
\hline \multicolumn{3}{|l|}{ Education } \\
\hline No formal education & 39 & 38.3 \\
\hline Primary education & 23 & 22.5 \\
\hline Secondary education & 24 & 23.5 \\
\hline Tertiary education & 16 & 15.7 \\
\hline Total & 102 & 100 \\
\hline \multicolumn{3}{|l|}{ Occupation } \\
\hline Farmer & 15 & 14.7 \\
\hline Artisan & 05 & 4.9 \\
\hline Retired & O3 & 2.9 \\
\hline Unemployed & 36 & 35.3 \\
\hline Civil servant & 32 & 31.4 \\
\hline Others & 11 & 10.8 \\
\hline Total & 102 & 100 \\
\hline
\end{tabular}


From Table 1, it can be seen that $37.3 \%$ of the respondents have not had formal education before, $32.3 \%$ of respondents are Primary School certificate holder, $15.7 \%$ of the respondents have attended Secondary School, while only $12.7 \%$ have been to tertiary educational institutions. One can infer from the result of the findings above that the educational status of most of the respondents is low. Therefore, most of them may not have much awareness of the effects of poor solid waste disposal to their health and the environment.

\subsection{Waste Generation and Disposal in the Study Area}

The findings of the study show that the type of waste generated in the study area according to $37.3 \%$ of the respondents is garbage, $32.3 \%$ rubbish, trash $15.7 \%$, and effluent $12.7 \%$ (Table 2 ).

\begin{tabular}{l|l|l|l}
\multicolumn{5}{c}{ Table-2. Type of Waste Generated in the Study area } \\
\hline S/No & Type of Waste & Frequency & Percentage \\
\hline 1 & Garbage & 38 & 37.3 \\
\hline 2 & Rubbish & 33 & 32.3 \\
\hline 3 & Trash & 16 & 15.7 \\
\hline 4 & Effluent & 13 & 12.7 \\
\hline 5 & Total & 102 & 100 \\
\hline
\end{tabular}

Most of the wastes are collected temporary for a short period of time before they are finally disposed off. The waste collection facilities according to respondent's opinion are open waste bin (30.4\%), close waste bin (50\%), plastic bags (15.7\%) and others $3.9 \%$ (Table 3 ). When the wastes are collected, they are transported to the dumping sites.

Table-3. Types of Waste Collection Facilities

\begin{tabular}{l|l|l|l}
\hline S/No & Types of Waste Storage & Frequency & Percentage \\
\hline 1 & Open waste bin & 31 & 30.4 \\
\hline 2 & Close waste bin & 51 & 50.0 \\
\hline 3 & Close plastic bags & 16 & 15.7 \\
\hline 4 & Others & 04 & 3.9 \\
\hline 5 & Total & 102 & 100 \\
\hline \multicolumn{2}{l}{}
\end{tabular}

Findings from the study shows that most of the waste $(37.3 \%)$ were transported by trucks while $48 \%$ of the respondents claimed that the waste are transported to dumpsites manually on the head, and $11.8 \%$ claimed that waste are transported through waste van and $2.9 \%$ claimed other means (Table 4 ).

Table-4. Mode of Transportation of Waste

\begin{tabular}{l|l|l|l}
\hline S/No & Mode of Transportation Waste & Frequency & Percentage \\
\hline 1 & Manually on head & 38 & 37.3 \\
\hline 2 & Use of trucks & 49 & 48.0 \\
\hline 3 & Use of waste van & 12 & 11.8 \\
\hline 4 & Others & 03 & 2.9 \\
\hline 5 & Total & 102 & 100 \\
\hline \multicolumn{2}{l}{ Source: Fieldwork, 2017. }
\end{tabular}

The solid wastes generated in Jalingo metropolis can either come from residential premises (households), industries, markets, shops, offices (Government and private), and municipal areas. Wastes collected from the residential premises are either sent to the community collection centers (temporary dumpsites) or taken directly to the main disposal site (located in the area). Households often accumulate wastes outside their houses in plastic bags (cement bags, fertilizer bags and small plastic bags).

The methods of waste disposal in the study area according to the respondent's opinion include open waste bin $54 \%$, open dumpsites $33.3 \%$, burying in landfills $8.8 \%$ and others $3.9 \%$ as shown in Table 5 .

Table-5. Method of Waste Disposal

\begin{tabular}{l|l|l|l}
\hline S/No & Method of Waste Disposal & Frequency & Percentage \\
\hline 1 & Use of waste bin & 55 & 54.0 \\
\hline 2 & Open dumpsites & 34 & 33.3 \\
\hline 3 & Burying in landfills & 9 & 8.8 \\
\hline 4 & Others & 4 & 3.9 \\
\hline 5 & Total & 102 & 100 \\
\hline
\end{tabular}

\subsection{Causes of Improper Waste Disposal}

When the respondents were asked the causes of poor waste disposal in the study area, $39 \%$ of the respondents attributed it to indifferent attitude of the residents in the study area, $35 \%$ of the respondents claimed it is the lack of waste disposal facilities, $22 \%$ lack of waste services and $6 \%$ to institutional failure (Table 6 ).

Table-6. Causes of Poor Waste Disposal

\begin{tabular}{l|l|l|l}
\hline S/No & Causes of Poor Waste Disposal & Frequency & Percentage \\
\hline 1 & Lack of waste service & 22 & 21.6 \\
\hline 2 & Indifferent attitude of residents & 39 & 38.2 \\
\hline 3 & Lack of waste disposal facilities & 35 & 34.3 \\
\hline 4 & Institutional failure & 06 & 5.9 \\
\hline 5 & Total & 102 & 100 \\
\hline
\end{tabular}


Findings from the study shows that most of the waste generated in the town come from residential households, market places, business shops, government and private offices and municipal areas. Most of the waste generated are either disposed off the street or any nearby dumpsite (mostly unapproved and illegal).

Abul [12] identified 6 approved dumpsites and 92 unapproved dumpsites in the study area. Findings from field observation show the presence of few movable waste disposal containers located in some few wards and streets in the study area.

\subsection{Awareness and Perception of Effects of Poor Waste Disposal}

When the respondents were asked if they know what constitute poor waste disposal, $24.5 \%$ claimed that it is pouring of effluent on the street, $22.5 \%$ claimed that it is dropping rubbish randomly, $44.2 \%$ claimed that it is dumping refuse in open dumps, while $8.8 \%$ claimed that it is burning of waste materials in open space (Table 7 ).

Table-7. Description of Poor Waste Disposal

\begin{tabular}{l|l|l|l}
\hline S/No & Description of Poor Waste Disposal & Frequency & Percentage \\
\hline 1 & Pouring of effluent on the street & 35 & 24.5 \\
\hline 2 & Dropping of rubbish randomly & 23 & 22.5 \\
\hline 3 & Dumping of refuse in open dumps & 45 & 44.2 \\
\hline 4 & Burning of waste materials & 11 & 8.8 \\
\hline 5 & Total & 102 & 100 \\
\hline
\end{tabular}

It has been observed that indiscriminate dumping of solid waste has become a common practice in most urban centres in Nigeria. The increasing rate of this practice is attributed to increasing urbanization, rapid population growth, deterioration in standard of living, poor governance and low level of public awareness of the effect of indiscriminate waste disposal among others. Findings from the study shows that $92 \%$ of the respondents claimed that they are aware of the effects of poor waste disposal while $8 \%$ claimed that they are not aware of the effects of poor waste disposal. On the description of waste disposal method in the study area by the respondents, $45.1 \%$ claimed that their present practice is safe, $12.7 \%$ claimed it is environmentally friendly, $36.3 \%$ insist it is environmentally harmful and 5.9\% claimed that they don't know (Table 8).

Table-8. Description of Efficiency of Waste Disposal Methods in the study area

\begin{tabular}{l|l|l|l}
\hline S/No & Description of Efficiency of Waste Disposal & Frequency & Percentage \\
\hline 1 & Very safe & 46 & 45.1 \\
\hline 2 & Environmentally friendly & 13 & 12.7 \\
\hline 3 & Environmentally harmful & 37 & 36.3 \\
\hline 4 & Don't know & 06 & 5.9 \\
\hline 5 & Total & 102 & 100 \\
\hline \multicolumn{2}{l}{ Source: Fieldwork, 2017. }
\end{tabular}

On the effects of poor waste disposal, $44.1 \%$ of the respondents claimed that it is associated with offensive odour, $18.6 \%$ claimed that it is a breeding ground for insect parasites, $8.8 \%$ believed that it affects the aesthetic quality of the environment, $5.9 \%$ claimed it blocked drainages and $17.7 \%$ claimed that it caused health problems (Table 9).

Table-9. Effects of Poor Waste Disposal

\begin{tabular}{l|l|l|l}
\hline S/No & Effects of poor Waste Disposal & Frequency & Percentage \\
\hline 1 & Offensive odour & 45 & 44.1 \\
\hline 2 & Breeding ground for parasites & 19 & 18.6 \\
\hline 3 & Eyesore & 09 & 8.8 \\
\hline 4 & Aesthetic problem & 05 & 4.9 \\
\hline 5 & Blockage of drains & 06 & 5.9 \\
\hline 6 & Health problems & 18 & 17.7 \\
\hline 7 & Total & 102 & 100 \\
\hline \multicolumn{2}{l}{ Source: Fieldwork, 2017. } &
\end{tabular}

Ebikapade, et al. [11] findings show that the more the public are informed on waste management matters, the better their perception and attitude towards environmental issues. The finding which was consistent with the findings of Rahardyan, et al. [13] shows that publicity increases awareness, and with increased awareness; residents are better disposed to participating in waste management in their community.

\subsection{Waste Management in the Study Area}

The study sought to find out if there is any waste management policy in existence. $49 \%$ of the respondents claimed that there is waste management policy in place while $51 \%$ of the respondents claimed there was none in existence. On the existence of community participation in waste management, $68 \%$ of the respondents claimed that there is while $32 \%$ claimed that there is none. When asked to suggest efficient method of waste management in the study area, 57\% suggest waste recycling, $24 \%$ claimed that it is burying in public landfills, $19 \%$ suggest incinerators and $2 \%$ suggest other methods (Table 10 ). 
Table-10. Efficient Methods of Waste Management

\begin{tabular}{l|l|l|l}
\hline S/No & Efficient Methods of Waste Management & Frequency & Percentage \\
\hline 1 & Recycling of waste & 57 & \\
\hline 2 & Incineration & 19 & \\
\hline 3 & Burying in public landfill & 24 & \\
\hline 4 & Others & 02 & \\
\hline 5 & Total & 102 & \\
\hline \multicolumn{2}{l}{ Source: Fieldwork, 2017. }
\end{tabular}

$66 \%$ of the respondents claimed that they adopt waste minimization strategy and $36 \%$ claimed that they don't. Also, $52 \%$ of the respondents claimed that the segregate the waste materials before disposal while $48 \%$ claimed that they don't segregate the waste before disposal.

\section{Discussion of Findings}

The increase in waste generation in most urban centres in Nigeria in recent times has risen astronomically as a result of urbanization and industrialization. Effective waste management has become an intractable problem beyond the capacity of most municipal authority in most developing countries. Effective solid waste disposal has become one of the challenges of urban centres in contemporary times that have defied all solutions by both state and Federal government and non-governmental organizations.

The increasing population in urban areas has outstripped the weak and inadequate infrastructure for waste management, resulting in refuse heaps that is left only to burning method and exposures to open landfills Adejobi and Olorunnimbe [5]. Abd'razack, et al. [14] observed that many parts of Jalingo town especially the central business districts do not benefit from any organized waste management services.

Solid wastes are usually unattended to, and in some cases either buried or burnt without taking into consideration the effects on the environment. Due to poor management and lack of public awareness, many parts of Jalingo metropolis is littered with solid waste which constitutes health hazards to the general public.

Other causes of poor solid waste disposal in the study area include lack of good and enough infrastructures, non-implementation of existing environmental sanitation laws and regulations, irregular and unplanned dumping of solid wastes, population growth due to rural-urban migration, insufficient capital to manage solid waste and lack of new technology in effective solid waste disposal [7].

Moreover, lack of awareness and active involvement of the households as key stakeholders in service provision and unwillingness to pay for solid waste collection and disposal in the study area contributes to poor solid wastes disposal in the area. The most common solid waste disposal method in the study area is open dumpsites. However, open dumpsites are good sources of environmental pollution (polluting soil, ground and surface water) due to the fact that they usually contain almost all types of pollutants from the initial collection sources $[15,16]$.

Open dumping of food wastes results in various environmental and health hazards. The decomposition of organic materials produces methane, which can cause fire and explosions and contributes to global warming [5]. This health hazards can include contamination of surface and ground water through direct waste contacts or leachate, air pollution by burning of wastes, spreading of diseases by different vectors like birds, insects and rodents, or uncontrolled release of methane by anaerobic decomposition of waste.

Thus, inadequate collection and improper waste disposal facilitates multiplication of pathogens causing diseases like cholera and diarrhea and provides favourable breeding ground for disease vectors like mosquitoes (malaria), flies (diarrhea) and rodents [12,17]. Proper solid waste disposal is a big problem in most urban centres especially in developing countries and Sub Saharan Africa in particular.

The intensity of solid waste management problem increases with increased population resulting from increased human activities and the volume of solid wastes to be disposed. Industries and urban municipal areas generate large amount of solid wastes that are often dumped in open field. The safe alternative to open dumpsites which is sanitary landfill, is a site where wastes are disposed at a carefully selected location constructed and maintained by means of engineering techniques that minimize pollution of air, water and soil, as well as other risks to humans and animals.

Loans or grants to construct sanitary landfills do not necessarily result in sanitary landfill disposal [5]. Unlike other larger urban centres in Nigeria where government agencies and officials move from house to house to collect solid waste from households, there is no such arrangement in Jalingo town. There are no private firms that are engaged in waste collections.

This may be attributed to the low level of willingness to pay for such services as a result of the low value placed on solid waste disposal in the study area. This is further made worst by the lack of sanitary health workers that in the past, move from house to house, shops and business areas to enforced sanitary regulations in the town.

The monthly compulsory sanitation usually observed by residents in the town in the early hours (0700 to $1000 \mathrm{hrs}$ ) of last Saturday of the month is no longer operational. Casual workers that were employed to cleanup major streets and institutional areas in the town have quit the job because of many years of unpaid wages.

\section{Conclusion}

This study has examined the level of public perception and awareness of the effects of poor solid wastes disposal in Jalingo Metropolis. Although Jalingo is not an industrial town, increase in population over the years has led to increasing rate of urbanization with the attendant problem of indiscriminate solid waste disposal. From the study, $39 \%$ of the respondents attributed the causes of poor waste disposal to indifferent attitude of the residents, $35 \%$ to lack of waste disposal facilities, $22 \%$ lack of waste services and $6 \%$ to institutional failure. The findings show that most of the wastes generated in the town come from residential households, market places, business shops, government and private offices and municipal areas. Most of the wastes are either disposed of the street or any nearby dumpsite (mostly unapproved and illegal). Most of the respondents claimed to be aware of what constitutes solid waste and effects of poor disposal. However, this claim negates attitude of indiscriminate solid waste disposal 
in the study area as revealed by the increasing number of open waste dumpsites and wastes that litters most streets of the town. Solid waste generated by the daily activities of the people needs to be properly managed in such a way that it minimizes the risk to the environment and human health.

\section{Recommendations}

Based on the findings of this study, the following recommendations are suggested;

i. Increase enlightenment campaign through jingles in mass media.

ii. Recruitment and empowerment of community health workers and sanitary officers.

iii. Reactivation of the monthly environmental sanitation programme

\section{References}

[1] K. Boadi and M. Kuitunen, "Environmental and health impacts of household solid waste handling and disposal practices in third world cities: The case of the Accra Metropolitan Area, Ghana," Journal of Environmental Health, vol. 68, p. 32-37, 2005.

[2] I. Abdullahi, M. A. Ajibike, A. P. Man-ugwueje, and O. I. Ndububa, "Environmental impact of indiscriminate waste disposal a case study of Nigerian Air Force Base Kaduna," International Journal of Engineering and Applied Sciences, vol. 1, pp. 25-33, 2014.

[3] A. Chengula, B. K. Lucas, and A. Mzula, "Assessing the awareness, knowledge, attitude and practice of the community towards solid waste disposal and identifying the threats and extent of Bacteria in the solid waste disposal sites in Morogoro Municipality in Tanzania," Journal of Biology, Agriculture and Healthcare, vol. 5, pp. 54-65, 2015.

[4] M. M. Rahman and M. A. Ali, "Waste management and environmental pollution in Bangladwsh," presented at the Intl Conf. Bangladesh Environ., ICBEN, BUET, Dhaka, Bangladesh, 2000.

[5] O. Adejobi and R. Olorunnimbe, "Challenges of waste management and climate change in Nigeria: Lagos State metropolis experience," African Journal of Science and Research, vol. 7, pp. 346-362, 2012.

[6] A. Bogoro, Y. Mohammed, and Y. Yakubu, "Indiscriminate solid waste disposal in Bauchi: Causes and impacts on the community and environment," Journal of Environment and Earth Science, vol. 3, pp. 40-54, 2013.

[7] N. S. Momodu, K. O. Dimuna, and J. E. Dimuna, "Mitigating the impact of solid wastes in urban centres in Nigeria," Journal of Human Ecology, vol. 34, pp. 125-133, 2011 .Available at: https://doi.org/10.1080/09709274.2011.11906377.

[8] O. A. Rachel, H. Komine, K. Yauhara, and S. Murakami, "Municipal solid waste management in developed and developing countries: Japan and Nigeria as case studies," Solid Waste Audit Report. Federal Capital Territory, Abuja Nigeria 20042009.

[9] C. I. Holland and M. J. Rosenberg, Attitude organization and change. New Haven: Yale University Press, 1996.

[10] B. Sarker, S. Sarker, M. Islam, and S. Sharmin, "Public awareness about disposal of solid waste and its impact: A study in Tangail Pourashava, Tangail," Journal of Environmental Science and Natural Resources, vol. 5, pp. 239-244, 2012.Available at: https://doi.org/10.3329/jesnr.v5i2.14821.

[11] A. Ebikapade, J. A. T. Omagbemi, and A. H. Syed, "Analysis of public participation in sustainable waste management practice in Abuja, Nigeria," Environmental Management and Sustainable Development, vol. 4, pp. 180-193, 2015.Available at: https://doi.org/10.5296/emsd.v4i1.7269.

[12] S. Abul, "Environmental and health impact of solid waste disposal at Mangwaneni dumpsite in Manzini: Swaziland," Journal of Sustainable Development in Africa, vol. 12, pp. 64-78, 2010.

[13] B. Rahardyan, T. Matsuto, Y. Kakuta, and N. Tanaka, "Resident's concerns and attitudes towards solid waste management facilities," Waste Management, vol. 24, pp. 437-45 1, 2004.Available at: https://doi.org/10.1016/j.wasman.2003.11.011.

[14] N. T. A. Abd'razack, A. E. Yusuf, and J. Z. Utange, "An appraisal of solid waste generation and management in Jalingo City, Nigeria," Journal of Environment and Earth Science vol. 3, pp. 20-30, 2013.

[15] G. R. Kassenga and S. E. Mbuligwe, "Impacts of a solid waste disposal site on soil, surface water and groundwater quality in Dar es Salaam City, Tanzania," Journal of Sustainable Development in Africa, vol. 10, pp. 73-94, 2009.

[16] S. Omofonmwan and J. Eseigbe, "Effects of solid waste on the quality of underground water in Benin Metropolis, Nigeria," Journal of Human Ecology, vol. 26, pp. 99-105, 2009.Available at: https://doi.org/10.1080/09709274.2009.11906171.

[17] S. M. Kassim and M. Ali, "Solid waste collection by the private sector: Households' perspective-Findings from a study in Dar es Salaam city, Tanzania," Habitat International, vol. 30, pp. 769-780, 2006.Available at: https://doi.org/10.1016/j.habitatint.2005.09.003. 